\title{
Theory of communicative action: a basis for the development of critical thinking
}

\author{
Teoria da ação comunicativa: subsídio para o desenvolvimento do pensamento crítico \\ Teoría de la acción comunicativa: subsidio para el desarrollo del pensamiento crítico
}

\section{Diana Paula de Souza Rego Pinto Carvalho', Allyne Fortes Vitor', Ana Luísa Petersen Cogo", Viviane Euzébia Pereira Santos', Marcos Antonio Ferreira Júnior ${ }^{1}$ \\ ' Universidade Federal do Estado do Rio Grande do Norte, Center of Health Sciences, Postgraduate Program in Nursing. Natal, Rio Grande do Norte, Brazil. \\ "Universidade Federal do Rio Grande do Sul, School of Nursing, Medical Surgical Nursing Department. Porto Alegre, Rio Grande do Sul, Brazil.}

How to cite this article:

Carvalho DPSRP, Vitor AF, Cogo ALP, Santos VEP, Ferreira Júnior MA. Theory of communicative action: a basis for the development of critical thinking. Rev Bras Enferm [Internet]. 2017;70(6):1343-6.

DOI: http://dx.doi.org/10.1590/0034-7167-2016-0383

Submission: $07-14-2016$

Approval: 02-02-2017

\section{ABSTRACT}

Reflections on some assumptions of the theory of Communicative Action and the development of Critical Thinking in the context of training students in undergraduate nursing courses. The perspective is based on concepts of Jürgen Habermas, as a possibility for the development of critical thinking among the students of these courses. Communication is therefore understood as inherent in the training of nurses in a continuous, dynamic, dialogical process, with interventions that are related to the context of the students and that have meaning for them, in order to contribute to the promotion of Critical Thinking.

Descriptors: Education in nursing; Reflections; Philosophy in Nursing; Communication; Nursing.

\section{RESUMO}

Texto reflexivo que objetiva aproximar alguns pressupostos da teoria da Ação Comunicativa com o desenvolvimento do Pensamento Crítico no contexto da formação de estudantes nos cursos de graduação em Enfermagem. Trata-se de uma reflexão com embasamento em alguns conceitos de Jürgen Habermas, como uma possibilidade para o desenvolvimento do pensamento crítico nos estudantes desses cursos. Entende-se, portanto, a comunicação como inerente à formação dos enfermeiros em um processo contínuo, dinâmico, dialógico, com intervenções associadas ao contexto dos estudantes e que tenham significado para eles, a fim de contribuir para a promoção do Pensamento Crítico.

Descritores: Educação em Enfermagem; Pensamento; Filosofia em Enfermagem; Comunicação; Enfermagem.

\section{RESUMEN}

Texto reflexivo que objetiva aproximar algunos presupuestos de la teoría de la Acción Comunicativa con el desarrollo del Pensamiento Crítico en el contexto de la formación de estudiantes en los cursos de graduación en Enfermería. Se trata de una reflexión basada en algunos conceptos de Jürgen Habermas, como una posibilidad para el desarrollo del pensamiento crítico en estudiantes de esos cursos. Se entiende, por lo tanto, la comunicación como inherente a la formación de los enfermeros en un proceso continuo, dinámico, dialógico, con intervenciones asociadas al contexto de los estudiantes y que tengan significado para ellos, a fin de contribuir para la promoción del Pensamiento Crítico.

Descriptores: Educación en Enfermería; Pensamiento; Filosofía en Enfermería; Comunicación; Enfermería. 


\section{INTRODUCTION}

Critical Thinking (CT) is a fundamental tool to face the complexity of modern scientific and technologically advanced life. In contemporary society, where know-how and knowledge are rapidly produced, it becomes an essential tool for the development of skills and attitudes ${ }^{(1)}$.

In this context, the ideal critical thinker is habitually curious, well-informed, honest in facing personal prejudices, prudent in decision-making, diligent in seeking relevant information, reasonable in selecting criteria, focusing on inquiry, and has a persistent search for results, which are as precise as the subject and the circumstances of consultation ${ }^{(2)}$.

The discussion and literary production around the development and teaching of $\mathrm{CT}$, as well as the respective competences and academic evaluations, constitute essential topics in education from the last decades of the twentieth century to the present day ${ }^{(1)}$.

In this way, CT in the teaching and learning process can be associated as an essential characteristic to the apprentice, since absorbing the content, forming an opinion and even questioning it whenever possible should be inherent in the contemporary student. Likewise, this interaction is mediated by communication between the teacher, student and reflections about the context into which they are inserted. To assume this posture, one must understand the logical connection between ideas; identify, construct and evaluate arguments; detect inconsistencies in reasoning; and solve problems systematically ${ }^{(1-2)}$.

In this context, when analyzing the health sector, there is a new paradigm in clinical practice represented by a reflective practice model, accompanied by the capacity for critical data analysis and based on continuous learning. Therefore, CT is a primordial element in the process of clinical reasoning ${ }^{(1)}$.

Consequently, following this process of change in nursing undergraduate education seeks to define CT and explain how the process of its development translates during the training and practice as a field of knowledge. Although this search persists for some time, nurses and educators continue to strive to promote CT skills in their students, given the importance they attribute to the development of such skills for vocational training(3).

The first definition of CT found in the context of Nursing training considered it an essential component for professional responsibility and quality care ${ }^{(4)}$. Thus, the professional nurse is expected to develop clinical reasoning together with $\mathrm{CT}$, to ensure appropriate care is provided, irrespective of the patient's, clinical, social and cultural circumstances.

On understanding CT as an attitude, a purposeful reflection and a process of development, the professional is expected to have their action, interaction and reaction mediated by communication that is inherent in the language ${ }^{(2)}$. Thus, the Theory of Communicative Action proposes conditions in which subjects, from an ideal situation or speech, seek to solve their impasses by using argumentative discourse that is free of coercion, in order to reach an understanding and elicit consensus ${ }^{(5-6)}$.

Therefore, this study aims to approximate some assumptions of the Communicative Action theory with the development of $\mathrm{CT}$ in the context of student training in undergraduate Nursing courses.

\section{THEORY OF COMMUNICATIVE ACTION}

Habermas proposes some important concepts to define the theory of Communicative Action, among them moral conscience, communicative action, dialogic knowledge and communicative rationality ${ }^{(6-7)}$.

To understand the importance of complete reversibility of the points of view, it is necessary to consider the moral conscience as a presupposition of the Theory of Communicative Action, from which the participants present their arguments; of universality, in the sense of an inclusion of all concepts; and of the reciprocity of equal recognition of the pretensions of each participant by all others ${ }^{(5)}$.

Dialogical knowledge and communicative rationality are collective and organized. Participants exercise their existential right to speak their mind, in respect and dialogue with others; Visions of the world are shared and discussed, not imposed, in a process of collective construction.

In Habermas' concept of communicative rationality, knowledge is given through the competence of dialogue, in the possibility of exchange, in giving to the other, with respect to the differences and sharing of the lifeworld present in the discussions about CT, since it is desirable that the student can identify the real meaning of elements and of these within a given context ${ }^{(4)}$.

In this aspect, the Communicative Action theory proposes to investigate the "reason" inscribed in everyday communicative practice and to reconstruct from the basis of validity of speech an unrestricted concept of reason, understood as the result of a learning, a social, communicative and dialogic evolution $^{(7)}$.

Therefore, communicative action blends the practice of argumentation, reflection and understanding, which seeks freedom from coercion and the imposition of ideas that impede creativity and critical knowledge, it can be characterized as a type of social action that through intersubjectivity aims at autonomy ${ }^{(4,7)}$.

In this context, communicative rationality develops via the intersubjective relation between the subjects, in a concise and open discourse, that allows realizing understanding and consensus. It is mainly based on understanding and learning.

Therefore, for communicative action to actually take place, it presupposes the following pretensions of validity: 1) every subject capable of acting and speaking can participate in discussions; 2) any participant in a dialog can problematize and introduce new affirmations, express their needs, desires and convictions; 3) no interlocutor can be prevented, by internal or external forces, from making use of his previously described rights ${ }^{(4)}$.

\section{CRITICAL THINKING AND THEORY OF COMMUNICATIVE ACTION}

In 1990, 46 specialists in the field of CT gathered at California State University for a consensus on how to define and measure critical thinking. Using the Delphi method, they presented a consensus list of cognitive skills essential for CT development: Interpretation (categorization, decoding and clarification of meaning); Analysis (evaluation of ideas, identification of arguments and analysis arguments); Assessment (evaluation 
of requests and evaluation of arguments); Inference (consult evidence, conjecture alternatives and draw conclusions); Explanation (results at each stage, justification of procedures, presentation of arguments); Self-regulation (self-examination and self-correction) $)^{(2)}$.

The definition of CT involves a process of logical, situational, purposive and individual reasoning. Therefore, the prerequisites are the teachers' attitudes and the students' abilities, associated to a systematic body of knowledge. Habermas believes that knowledge is the understanding between the educator and the student, while Facione suggests that $\mathrm{CT}$ should be stimulated by its inherent skills associated to the student's interest ${ }^{(2,7)}$.

Communicative action in the production of knowledge promotes changes from the knowledge of the problems that affect the various sectors of society and the scientific research to solve them ${ }^{(4)}$. In the meantime, the student in formation realizes his or her importance and commitment to society and demonstrates autonomy, which contributes to a change in attitude.

Therefore, it is necessary to exercise Habermas' communicative action and communicative rationality to promote the necessary skills of a competent critical thinker, both by the teacher and the student, with discussions on everyday situations of nursing, as well as to strengthen nursing as a profession and discipline; besides consolidating a science with personality and defined field of action.

In this way it can no longer be accepted that pedagogical training does not consider dialogue as the space to expose ideas and debate proposals. Thus, Nursing undergraduate courses, as training environments for future professionals, are responsible for promoting communicative action, using dialogue and stimulation of CT, to construct thinking and reflections about the thought process itself within the day-to-day situations of nursing.

\section{INFLUENCE OF COMMUNICATIVE ACTION THEORY ON CRITICAL THINKING IN THE TEACHING OF NURSING}

Recent studies have shown that some strategies have a better performance in the promotion of CT among undergraduate Nursing students, such as Problem Based Learning (PBL), Simulation, Concept Mapping, reflection and the association between two or more strategies ${ }^{(8-9)}$.

In this way, understanding the classroom as an environment for CT promotion is essential in nursing education, as well as understanding the nurse as an educator who is a responsible and ethical professional, creating an environment conducive to learning in which the aim is to train competent, effective and autonomous nurses ${ }^{(8-9)}$. Nursing educators should provide a captivating and interesting teaching and learning process in Nursing programs that focus on the development of these ideals.

\section{Process for training the professional nurse}

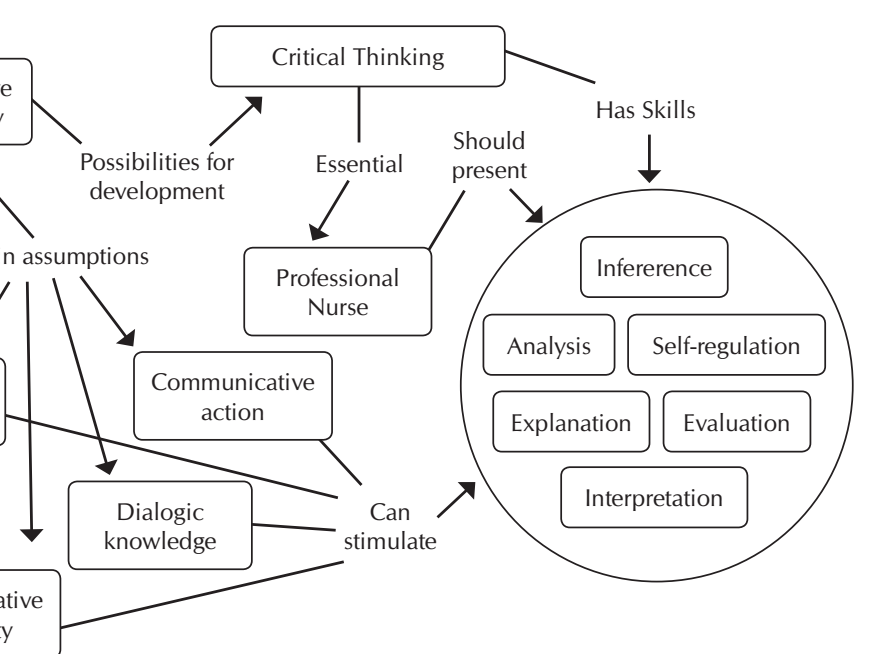

Conceptual map illustrating the process of training nursing professionals by approximating Communicative Action Theory with Critical Thinking

Figure 1 presents a conceptual map with the interrelation between the Theory of Communicative Action and the development of the $\mathrm{CT}$ in the process of training the nursing professional in understanding communicative rationality, moral conscience, communicative action and dialogic knowledge as fundamental characteristics for mediating the promotion of each skill necessary to think critically.

The CT skills presented in Figure 1 reflect how certain assumptions can stimulate their development, since action, the quest for knowledge, reason and awareness can be mediated by educators during the training process.

Among the teaching strategies capable of promoting the development of CT is the construction of conceptual maps (CM), since in their preparation the student must seek the knowledge acquired, relate the various concepts that integrate it and form final propositions, from broader terms to examples of everyday situations ${ }^{(10)}$.

Therefore, the intentionality is underscored of having opted for its use is demonstrated by the relationship between the assumptions of Communicative Action Theory and CT skills as inherent to the contemporary nurse. Communicative action is intrinsic to the profession, since communication and action allow the nurse to understand the reality and situation in which the patient is inserted and to act according to the diversity presented in the context.

Teaching strategies guided by the Theory of Communicative Action can promote the development of $\mathrm{CT}$ in nursing teaching, as demonstrated in some studies in which reflective activities help nursing students to understand and communicate past experiences that in turn help to shape perceptions and assumptions of the nursing profession ${ }^{(8,10)}$. This, as in CMs, simulation is also a teaching strategy that, when mediated by communicative action, can provide students with clinical experiences that assess decision making and consequently stimulate the development of CT and communication skills to heighten patient safety. 
One study reported that Nursing students present capabilities for CT development and should be encouraged in the construction of a "disciplined mind" that involves the characteristics of CT necessary for professional practice. It also indicates the importance of a selection of best strategies for the promotion of CT in Nursing training, in order to assist educators with the integration of techniques that favor the development of CT in Nursing curricula ${ }^{(8)}$.

In this context, the training of nurses must be continuous, dynamic, dialogic, with teaching strategies associated with the reality of students and whose content has meaning for them in order to contribute to the promotion of dialogue and discursive ethics in the moments of learning. Training should be built by the educator-student relationship and other participants at the time of learning through an inclusive dialogue of the real facts associated with clinical reasoning and quality care.

\section{FINAL CONSIDERATIONS}

Communicative rationality, communicative action, moral awareness and dialogic knowledge are presuppositions of Communicative Action Theory. They are presented as a possibility of interrelationship with CT skills, since communication, action and interaction go hand-in-hand to promoting their development in undergraduate Nursing students; by stimulating analysis, explanation, interpretation, assessment, inference, explanation and self-regulation.

Consequently, communication mediated by a coherent, receptive and reflective discourse in a situational context between and from the subjects should be encouraged. Thereby contributing to professional nursing training with the objective of representing a possibility for the development of much desired CT skills in Nursing education.

\section{REFERENCES}

1. Amorim MP, Silva I. Instrumento de avaliação do pensamento crítico em estudantes e profissionais de saúde. Psic Saúde Doenças [Internet]. 2014[cited 2016 Jun 01];15(1):122-37. Available from: http://www.redalyc.org/articulo.oa?id= 36231157011

2. Facione PA. Critical thinking: what it is and why it counts. California Academic Press. Millbrae, CA [Internet]. 2011 [cited 2016 Mar 30]. Available from: www.insightassessment.com

3. Lovatt A. Defining critical thoughts. Nurse Educ Today [Internet]. 2014[cited 2016 Jun 01];34(5):670-2. Available from: http:// www.nurseeducationtoday.com/article/S0260-6917(13)00425-5/abstract

4. Habermas J. Consciência moral e agir comunicativo. Rio de Janeiro: Tempo Brasileiro; 1989.

5. Schefer BK, Rubenfeld MG. A consensus statement on critical thinking in nursing. J Nurs Educ [Internet]. 2000 [cited 2016 Jun 01];39(8):352-9. Available from: http://www.ncbi.nlm.nih.gov/pubmed/11103973

6. Muhl EH. Habermas e a Educação: Racionalidade comunicativa, diagnóstico crítico e emancipação. Educ Soc [Internet]. 2011[cited 2016 Jun 01];32(117):1035-50. Available from: http://www.scielo.br/pdf/es/v32n117/v32n117a08.pdf

7. Habermas J. Teoria de la acción comunicativa. Tomos I e II. Madri: Taurus, 1988.

8. Burrell LA. Integrating critical thinking strategies into nursing curricula. Teach Learn Nurs [Internet]. 2014 [cited 2016 Jun 01];9(2):53-8. Available from: http://www.sciencedirect.com/science/article/pii/S155730871300142X

9. Carter AG, Creedy DK, Sidebotham M. Efficacy of teaching methods used to develop critical thinking in nursing and midwifery undergraduate students: A systematic review of the literature. Nurse Educ Today [Internet]. 2016[cited 2016 Jun 01];40:209-18. Available from: http://www.nurseeducationtoday.com/article/S0260-6917(16)00116-7/abstract

10. Andreou C, Papastavrou E, Merkouris A. Learning styles and critical thinking relationship in baccalaureate nursing education: a systematic review. Nurse Educ Today [Internet]. 2014[cited 2016 Jun 01];34(3):362-71. Available from: http://www. nurseeducationtoday.com/article/S0260-6917(13)00204-9/abstract 